\title{
Trend Analysis of Climate Variability over the West Bank - East London Area, South Africa (1975-2011)
}

\author{
Kalumba A. $\mathrm{M}^{1}$, Olwoch J. $\mathrm{M}^{2}$, I. van Aardt ${ }^{1}$, Botai O. $\mathrm{J}^{1}$, Tsela $\mathrm{P}^{1}$, Nsubuga F. W. $\mathrm{N}^{1}$ \& Adeola A. $\mathrm{M}^{1}$ \\ ${ }^{1}$ Department of Geography, Geoinformatics and Meteorology, University of Pretoria, Pretoria 0028, South \\ Africa \\ ${ }^{2}$ South African National Space Agency (SANSA), Silverton 0127, South Africa \\ Correspondence: Kalumba A. M, Department of Geography, Geoinformatics and Meteorology, University of \\ Pretoria, Pretoria 0028, South Africa. E-mail: mkalumba@gmail.com
}

Received: October 17, 2013 Accepted: November 10, 2013 Online Published: November 22, 2013

doi:10.5539/jgg.v5n4p131 URL: http://dx.doi.org/10.5539/jgg.v5n4p131

\begin{abstract}
In recent years, climate change has received considerable attention by the scientific community at different scales concerning its potential impacts on Earth system processes. This study focused at local scale by analysing trends in rainfall and temperature data for the West Bank-East London area in South Africa, spanning 36 years from 1975-2011. Sen's and Man-Kendall non-parametric tests were performed on derived mean observed rainfall and temperature data to establish trends for monthly, seasonal, annual, and 30 year (1975-2005 and 1980-2011) climatic regimes. Results revealed that, 1977 recorded the highest annual rainfall $(2272.9 \mathrm{~mm})$ while the month of August received the highest total rainfall $(493.8 \mathrm{~mm})$ in 2002 , whereas it never had rain in 1995. Seasonal and annual rainfall showed statistically no significant trend (at $a=0.10$ ) while the magnitude of change varied between $1.87 \mathrm{~mm}$ (January) and $-1.67 \mathrm{~mm}$ (September) across the study period. Rainfall decreased by $13.99 \mathrm{~mm}$ within the two climatic regimes. On the other hand, maximum and minimum annual mean temperature experienced an increasingly statistically significant trend (at a $<0.05)$ at $95 \%$ confidence level. February recorded the highest mean monthly temperature $\left(21.8^{\circ} \mathrm{C}\right)$ while July with the lowest $\left(12.6{ }^{\circ} \mathrm{C}\right)$. Seasonal mean maximum temperature trends were statistically not significant $(\mathrm{a}=0.10)$ while autumn minimum temperatures revealed a statistically significant trend (at a $<0.1$ ). However, the period 1990-1999 predominantly experienced numerous extreme events. The seasonal trends showed substantial variability across the months and years during the study period. The significance of these findings lies in the linkage of rainfall and temperature to climate change and its potential impacts on vegetation in particular and changes in the ecology in general.
\end{abstract}

Keywords: rainfall, temperature, variability trend analysis, West Bank-East London, Sen's and Man-Kendall

\section{Introduction}

One of the most significant facts that humans have ignored and which became well appreciated in the twentieth century was that climate and the entire environment is changing far more-faster and significantly than it had ever been imagined. This has seen a political rhetoric and the branding of environmental activists as extremists. However, the reality is that the effects, risks and uncertainty with the science around the subject of climate change are daunting, challenging and complex to understand. This is perhaps true that the issue of climate change is the most controversial in the entire science of meteorology (Ekpoh \& Nsa, 2011). In the recent years the potential impacts of Climate Variability and Change (CVC) have received considerable attention from researchers and as such, both temporal and spatial dimensions have been documented based on rainfall and temperature climate parameters across the world (e.g., Jury, 2013; Kenawy et al., 2009; López-Moreno et al., 2009; Helmes et al., 1996). However, very few studies considered both climate parameters in their studies using either Mann-Kendall test (Mann, 1945; Kendall, 1975) or Sen's estimator (Sen, 1968). The effects of CVC range from a few positive to vast negative ones across different places at a local and global scale. As a result the Intergovernmental Panel on Climate Change (IPCC) has taken a centre stage in trying to mobilize the world to live in a sustainable way and focus on developing strategies for adaptation to climate change impacts on the entire ecosystem. This is because CVC can be attributed directly or indirectly to human activity that alters the composition of the global atmosphere and which is in addition to natural climate variability over comparable time periods (Midgley et al., 2005, cited in Mukheibir \& Sparks, 2005). The effects would be felt in decades to 
centuries. Therefore, information about such climatic changes is required at global, regional and basin scales for a variety of purposes (Arora et al., 2005) especially for Africa where one-third of the people live in arid climatic regime (Jury, 2013). This could worsen due to Africa having multiple stresses and low adaptive capacity (CSIR, 2011).

Rainfall trend studies reveal that there has been much variability in rainfall over different parts of the world. For instance, studies of extreme rainfall trends in general show that the frequency of more intense rainfall events in many parts of Asia increased whereas the number of rainy days and total annual precipitation decreased (Jain \& Kumar, 2012 and references therein). India's intra-seasonal component is intrinsically unpredictable (Krishnamurthy \& Shukla, 2000). López-Moreno et al. (2009) revealed that north-eastern Iberian Peninsula experienced very large spatial and seasonal precipitation variability between 1955 and 2006 period. Similarly, in Malawi Ngongondo et al. (2011) found a complex rainfall pattern with an increase in inter-annual rainfall variability countrywide. Nsubuga et al. (2011) and Kizza et al. (2009) studies revealed a positive trend for the intra-annual rainfall analysis at Namulonge and Lake Victoria region respectively. Jury (2013 and references therein) indicated that in southern Africa, long-term trends are weak but inter-annual rainfall variability has increased since 1970. In South Africa (SA), rainfall variability was projected through downscaling which revealed an increase in summer rainfall in the interior and the eastern part, and a decrease in winter rainfall in the Western Cape (Hewitson et al., 2006). Due to a number of weak oscillations identified such as the 18-year oscillation and the 10-12 year oscillation (Tyson, 1986) which influences rainfall variability over southern Africa in general (Mukheibir \& Sparks, 2005). Historical records indicate that inter-annual rainfall variability over SA is increasing (Mason, 1996), but in the Drakensberg region all stations show a non-significant change in variability of annual rainfall (Nel, 2009). However, an increase in the variability of the distribution of monthly rainfall was seen over Drakensberg (Nel, 2009). Similar scenarios have been reported that rainfall variability is particularly pronounced over the dry western parts of SA, where a dry year can have significant repercussions (Mukheibir \& Sparks, 2005) on people's livelihoods. Between 1931 and 1990, the intensity of extreme events increased significantly over SA (Mason et al., 1999; Tyson, et al., 2002). It has also been predicted that the mean rainfall in SA is expected to decrease between 5-10 percent within the next 50 years (Hewitson, 1999 as cited by Mukheibir \& Sparks, 2005). In addition, Mason et al. (1999) revealed that percentage increases in the intensities are largest for the most extreme rainfall events. Rainfall trends are important in the distribution and functioning of fauna and flora, and influence, for example, the spatial and temporal patterns of vegetation (Fernandez-Illescas \& Rodriguez-Iturbe, 2004; Nel, 2009). As a result the expected reduction in rainfall could have significant impacts on different sectors of SA's economy.

On the other hand, studies on temperature indicate a general upward (warming) trend in the global mean surface temperature at a fluctuating rate ranging between $0.3{ }^{\circ} \mathrm{C}$ and $0.6{ }^{\circ} \mathrm{C}$ over the last century (Kenawy et al., 2009 and references therein). Furthermore, it is estimated that temperature increased by 0.6 on average over the last century, and that by 2100 temperature increase could range between $1.4{ }^{\circ} \mathrm{C}$ to $5.8^{\circ} \mathrm{C}$ (IPCC, 2007 in Tshiala et al., 2011). In addition, Collins (2011 and references therein) notes that IPCC regional climate projections for Africa suggest that for West Africa, East Africa, South Africa, and the Sahara, regardless of the season temperatures are predicted to increase $\left(3{ }^{\circ} \mathrm{C}-4{ }^{\circ} \mathrm{C}\right)$ between 1900 and 2100 . In particular, a regional study by Mukheibir and Sparks (2005) indicates that temperature is expected to increase everywhere in SA, at approximately $1.5{ }^{\circ} \mathrm{C}$ along the coast and $2{ }^{\circ} \mathrm{C}-3{ }^{\circ} \mathrm{C}$ inland of the coastal mountains by 2050 . In addition, Kruger and Shongwe (2004) study reveals that between 1960 and 2003, SA's mean temperature increased by $0.13{ }^{\circ} \mathrm{C}$. Furthermore, other temperature studies conducted in SA reveal the same trend of an increasing temperature (Hughes \& Balling, 1999; Tshiala et al., 2011; Jones, 1994). This warming observed during the past 50 years is due to human activities and further increases are expected if carbon dioxide and greenhouse gas emissions are not controlled (IPCC, 2007). As a result, the predicted temperature increase could alter the earth-atmosphere balance which could lead to fluctuations in evaporation, relative humidity, soil moisture as well as the general water cycle. The impacts of climate change are potentially very high, particularly where water resources are already highly stressed in many areas, while the capacity to cope and adapt is not consistently high (Schulze, 2005; Mukheibir \& Sparks, 2005). This is a dilemma that SA finds herself in, and therefore up-to-date information is needed for proper planning.

So far, limited studies have focused on local or station analysis of climatic parameters and thus, could be an active area of research provided robust statistical methods are used. There is little or no known work reported in the literature on rainfall and temperature related trend studies over West Bank-East London area in SA for instance. Yet, micro climatic variability has huge influence on vegetation (Helmes et al., 1996) and local livelihoods for instance. At the same time, CVC has been seen as a reality (Nsubuga et al., 2011; Kruger \& 
Shongwe, 2004). As such, it warrants that an update on climate trends and magnitude information is provided to aid planning in conservation, agriculture and water among others. Therefore, the aim of this study was to analyse rainfall and temperature climatic variability trends and seasonal changes spanning the period 1975-2011 using nonparametric statistical methods over the West Bank-East London area in SA. In particular, the present work focused on analysing trends at monthly, seasonal and annual timescales for rainfall and temperature for the two climatic regime changes. Additionally, the current work explored seasonality rainfall and temperature relationships. The findings of this study are intended to contribute towards filling in the CVC gap by providing historic long-term trend information on rainfall and temperature changes, which could possibly serve as an important proxy during modelling procedures for projecting local climatic trends and extent of the changing climate impacts in the West Bank-East London area. Also the study highlighted areas for further research on the subject. Furthermore, this study has significant implications on vegetation conservation plans in the area. At the same time, the critical need that all parts of the world are examined for evidence of climate change especially extreme events (Easterling et al., 2003) was accomplished by the study's contribution.

\section{Material and Methods}

\subsection{Study Area Description}

This study was conducted using a weather station (00595729, East London-WK) located in West Bank-East London area, Buffalo City Metropolitan Municipality (BCMM) of the Eastern Cape Province in SA. The station (Figure 1) is situated at latitude: $-33.0330 \mathrm{~S}$ and longitude: $27.8330 \mathrm{E}$, to monitor the entire West Bank-East London area. The study area has an ecosystem characterised with ecologically sensitive vegetation species (see; Lubke, 1986). The area is situated between the Indian Ocean to the South, bounded by the Igoda River to the West, East London city to the East, and Buffalo River. This area also consists of rolling coastal plains with rock outcrops and hills separated by very steep sections within the valleys (BCMM, 2004). Generally, the average altitude around the weather station varies between 0 and 350 meters above mean sea level (amsl). The mean annual surface temperature ranges from $17{ }^{\circ} \mathrm{C}$ to $20^{\circ} \mathrm{C}$, while rainfall varies from $400 \mathrm{~mm}$ to $700 \mathrm{~mm}$ (BCMM, 2004). In particular, the climate is characterized with warm humid to hot dry summers and relatively mild winters with warm days and cool nights, while July experiences limited frost.

The vegetation in West Bank is broadly categorized into: littoral strand, dune forest (coastal thicket), transitional coastal forests, bush veldt, valley grasslands and savannah (Coastal Resource Management, 1994; Lubke, 1984) which is characterized as: endangered, rare, and endemic. Furthermore, the area is nestled by several industrial activities (such as the East London Industrial Development Zone-ELIDZ). Indeed, this area exhibits a mixed land use pattern. On the other hand, the weather station [Figure 1 (b)] has longer temporal records of observed climatic data stretching back beyond 1975. Until recently, this climatic data has not been temporally analysed thus was used in this study. With this, it was imperative to establish the state of the climate variability to help in fostering vegetation conservation plans especially for the rare and endemic species. Besides, scientific climatological analysis for this weather station data might help to identify changes in historical weather elements (rainfall and temperature) to design mitigation measures for the impacts on society in general. 


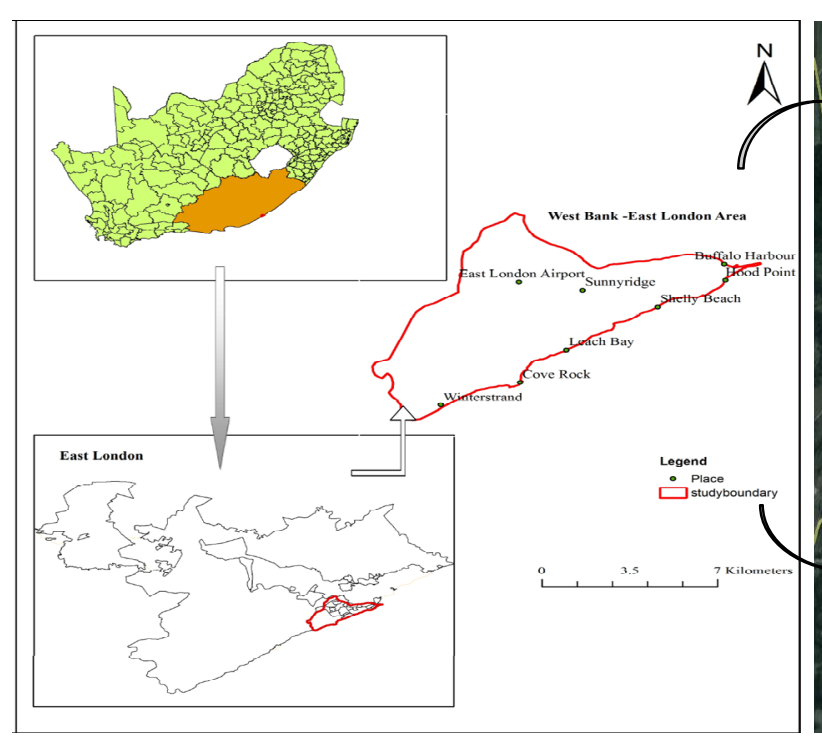

a)

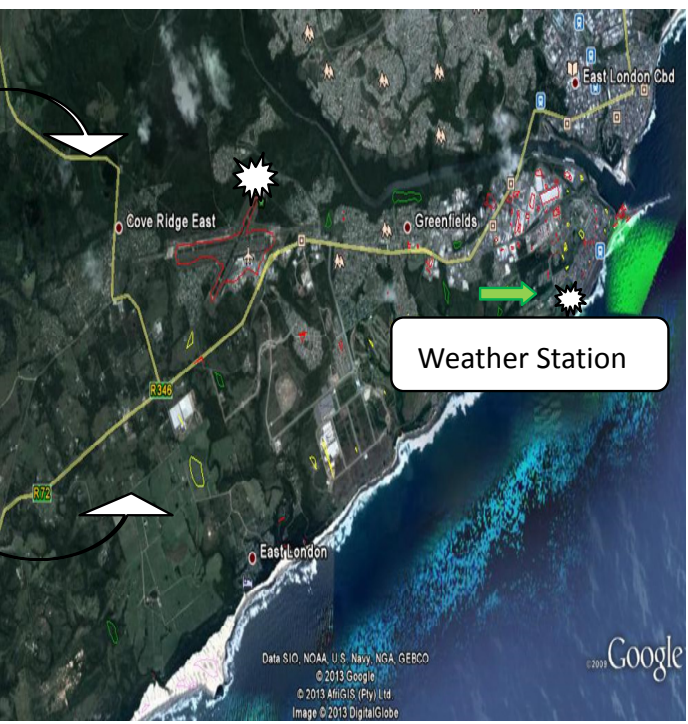

b)

Figure 1. The location of West Bank-East London Area in the Eastern Cape Province South Africa (a) and a Weather Station recording daily observed climatic data (b) for the study area

\subsection{Rainfall and Temperature Data Pre-Processing}

Climatic data sets for the period 1975 to 2011 used in this study were obtained from the South African Weather Services (SAWS) which comprised of daily observed rainfall and temperature estimates. To ensure that trend results are accurate, quality checks were performed on the entire data set to determine data completeness. In particular, visual inspection of rainfall and temperature plots (Nsubuga et al., 2011) was adopted, and where possible by replacing the missing gaps using infilling and record extension techniques developed by Schulze and Maharaj (2004). To this end, the gap filling exercise involved averaging the upper and lower values, to arrive at long term mean values. Although, only $1.8 \%$ of the missing data was observed, the data sets were generally considered to be comprehensive enough for the estimation of rainfall and temperature related variables. Consequently, these daily observed estimates for rainfall and temperature were averaged into monthly means over a period of 36 years. As a result, rainfall and temperature monthly means were computed and later uploaded into An Clim (v5.025) software (Štěpánek, 2008) and trend software (Chiew \& Siriwardena, 2005) for detailed analysis and graphical representation. Numerous time series were derived from these data sets such as; average monthly total rainfall, average monthly temperature, seasonal and annual variability.

\subsection{Seasonality Delineation}

Seasonality can be described through the monthly rainfall totals as percentages of the total annual rainfall (Nel \& Sumner, 2006; Nel, 2009). In this study, seasonality analysis for 36 years was based on monthly averages for rainfall and temperature recorded during 1975 to 2011. Consequently, each year was divided into four climatic seasons based on South Africa's weather patterns namely; spring (September to November-SON), summer (December to February-DJF), autumn (March to May-MAM) and winter (June to August-JJA). The same kind of monthly clustering has been widely adopted by different scholars in numerous studies across the world (e.g. Collins 2011; Nsubuga et al., 2011; Tshiala et al., 2011; López-Moreno et al., 2009; Kenawy et al., 2008; Kruger \& Shongwe, 2004). Therefore, in this study rainfall and temperature mean values were calculated based on monthly, seasonal, yearly and 30 year normal (i.e. two temporal periods; 1975 to 2005 and 1981 to 2011) classification analysis. The averages for each month and year provided smooth values for statistical analysis. In general, all climate variability related issues were flagged into An Clim software to provide relevant and empirical results for proper planning especially at household, municipal and regional.

\subsection{Methods Used in Trend Significance and Magnitude of Change Analysis}

Generic time series trend analysis consists of the magnitude of trend and its statistical significance (Jain \& Kumar, 2012). With the growing interest in the subject of CVCs and the associated impacts, scholars have considerably adopted non-parametric Mann-Kendall (MK) test (Mann, 1945; Kendall, 1975) and Sen's estimator (Sen, 1968) in analyzing time series of rainfall and temperature data to establish trends in climate change; 
especially if the data are non-normally distributed and/or have missing values (Arora et al., 2005). In the present study, the magnitude of trend in a time series was determined using Sen's estimator and statistical significance of trend using MK test non-parametric techniques. In determining the magnitude of a trend, Sen's method assumes a linear trend in the time series and it has been widely adopted in e.g., determining the magnitude of trend in hydro-meteorological time series (Jain et al., 2012 and references therein). The Sen's estimator was derived using Equations (1) and (2), where, the slopes (Ti) for both rainfall and temperature were computed (1):

$$
\mathrm{T} i=\frac{\mathrm{X}_{j}-\mathrm{X}_{k}}{j-k}
$$

For $i=1,2, \ldots . \mathrm{N}$,

where $X_{j}$ and $X_{k}$ are data values at time $\mathrm{j}$ and $\mathrm{k}(\mathrm{j}>\mathrm{k})$, respectively, and the median of these $\mathrm{N}$ values of T $i$ is the Sen's estimator of slope (Jain et al., 2012). This was computed using Equation (2) as follows;

$$
\beta=\left\{\begin{array}{l}
T \frac{N+1}{2} \\
\frac{1}{2}\left(T+T \frac{N+2}{2}\right)
\end{array}\right.
$$

$\mathrm{N}$ is odd or even.

A positive value of $\beta$ indicates an upward (increasing) trend and a negative value indicates a downward (decreasing) trend in the time series (Jain et al., 2012). This is expressed in the magnitude of change values.

In order to analyse the significance of trend, MK test was used based on the test statistic, S, which has been adopted widely (e.g., Jain et al., 2012; Jain \& Kumar, 2012; Nsubuga et al., 2011; Kizza et al., 2009). The MK test has been found to be robust to the effects of extremes and deviations from a linear relationship (Kizza et al., 2009). Furthermore, Jain et al. (2012) reported that the MK method searches for a trend in a time series without specifying whether the trend is linear or non-linear. The MK test checks the null hypothesis of no trend versus the alternative hypothesis of the existence of increasing or decreasing trend (Jain et al., 2012). Consequently, this method was adapted in this study to test whether there was a trend in the time series data. The $\mathrm{n}$ time series values $(\mathrm{X} 1, \mathrm{X} 2, \mathrm{X} 3, \ldots ., \mathrm{Xn})$ were replaced by their relative ranks (R1, R2, R3,...., Rn) (starting at 1 for the lowest up to $\mathrm{n}$ ). The test statistic $\mathrm{S}$ used is given in Equation (3):

$$
S=\sum_{i=1}^{n-1}\left[\sum_{j=i+1}^{n} \operatorname{sgn}(R i-R i)\right]
$$

where

$$
\begin{aligned}
& \operatorname{sgn}(x)=1 \text { for } x>0 \\
& \operatorname{sgn}(x)=0 \text { for } x=0 \\
& \operatorname{sgn}(x)=-1 \text { for } x<0
\end{aligned}
$$

Here, if the null hypothesis Ho is true, then $\mathrm{S}$ is approximately normally distributed with:

$\mu=0$

$$
\sigma=\mathrm{n}(\mathrm{n}-1)(2 \mathrm{n}+5) / 18
$$

The z-statistic (see Equation 5) is therefore (critical test statistic values for various significance levels can be obtained from normal probability tables) in which case, a positive value of S indicates that there is an increasing trend and vice versa. In the present analysis, the null hypothesis was tested at $95 \%$ confidence level.

$$
\mathrm{z}=|\mathrm{S}| / \sigma 0.5
$$

\section{Results and Discussion}

\subsection{Rainfall Changes and Trends}

Changes in rainfall quantity and frequency would alter the pattern of stream flows and demands for water (particularly agricultural), spatial and temporal distribution of runoff, soil moisture, and ground water reserves (Jain et al., 2012). In studying rainfall trends, the focus was on analysing monthly, seasonal, and annual rainfall 
of the two climatic regimes. This is because, temporal scale analysis provides a better understanding of the changes for planning at all levels especially with regards to vegetation conservation in West Bank-East London area.

\subsubsection{Analysis of Monthly and Seasonal Rainfall Trends}

Results on the analysis of monthly and seasonal rainfall trends and magnitude of change encompassing the period 1975-2011 for West Bank-East London area are presented (Table 1 and Figures 2-4). The maximum monthly annual rainfall $(493.8 \mathrm{~mm})$ was observed in 2002 during the month of August, and the lowest $(0.00 \mathrm{~mm})$ witnessed in May and August (1992 and 1995) respectively, see Figures 2 and 3, and Table 3. On the other hand, for the monthly rainfall totals (1975-2011), only January depicted a significant positive trend while the rest of the months showed a fluctuating increasing and decreasing scenarios which were not statistically significant (at $\mathrm{a}=0.10)$, see Table 1 . The highest monthly mean rainfall was observed in November $(115.86 \mathrm{~mm})$ and the lowest in June $(34.96 \mathrm{~mm})$ for the same period. Furthermore, there are some years like 2011, 1993, 1989 and 1975 that experienced extreme monthly rainfall events. The monthly pattern showed approximately constant rainfall totals between January and March $(81.0-88.6 \mathrm{~mm})$, April to August reveals lowest records $(63.23-69.99 \mathrm{~mm})$ and finally September to December $(73.2-115.86 \mathrm{~mm})$ with an aggregate progressive mean increase. In general, the monthly rainfall is higher during November, October, January, December and March (above $83.9 \mathrm{~mm}$ ), and the rest of the months shows a decreasing trend (Table 1). Consequently, the average monthly rainfall total (Figure 2 and Table 1) showed uneven distribution and variability in terms of trend (Figure 2), and magnitude of change (Table 1) varied between 1.87 (January) and -1.67 (September) across the study period.

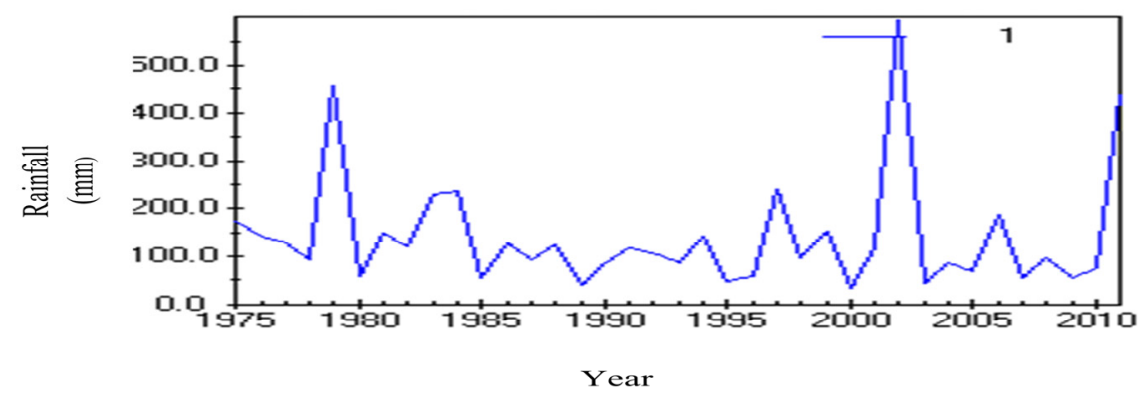

Figure 2. Monthly Average Rainfall Trend from 1975-2011 for West Bank-East London Area

Seasonal rainfall totals (Figure 3) showed highest recorded mean rainfall at $288.99 \mathrm{~mm}$ during SON season and lowest in JJA season at $141.32 \mathrm{~mm}$. This observation is comparable to Nel and Sumner's (2008) study in the Drankensburg where also winter rainfall was noted to be considerably lower. Considering the entire SON data set, 1985 received the highest amount of rainfall $(807.7 \mathrm{~mm})$ and the lowest observed was $72.5 \mathrm{~mm}$ in 1994 at a rate of $-21.5 \mathrm{~mm}$ per decade. The DJF season recorded the highest rainfall of $478.1 \mathrm{~mm}$ in the year 1981 and the lowest $62.0 \mathrm{~mm}$ in 1989 at a rate of $7.73 \mathrm{~mm}$ per decade (positive trend). The highest and lowest recorded monthly rainfall were in MAM season in $2000(485.2 \mathrm{~mm})$ and $1993(36.2 \mathrm{~mm})$ (Figure 3c), as well as the JJA season in $2002(593.0 \mathrm{~mm})$ and $2000(35.5 \mathrm{~mm})$ (Figure 3d) respectively for the entire study period. As a result, seasonal multi-decadal trend analysis depicted both negative (SON and JJA seasons) and positive (MAM and DJF seasons) trends. 

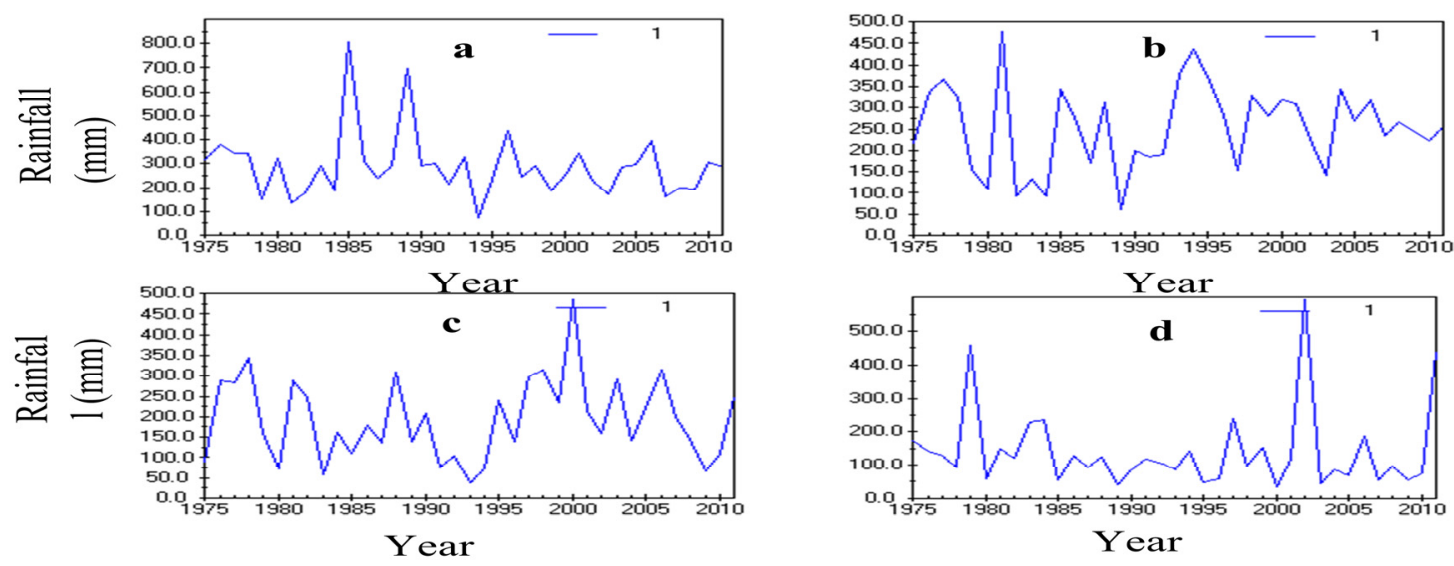

Figure 3. Seasonal rainfall: a) SON; b) DJF; c) MAM and d) JJA for West Bank - East London Area 1975-2011 trend analysis

Generally, West Bank-East London area rainfall analysis showed large variability in magnitude (Table 1) and direction of trend (Figures 2-3) for study period 1975-2011. Jury (2013) discovered that year-to-year climate variability is modulated by El Niño Southern Oscillation (ENSO), amongst other factors, and so the regional climate may exhibit an extended 'summer or winter'. Such finding could be used to explain why August received the highest amount of rainfall $(493.8 \mathrm{~mm}$ ) in 2002 (Figure 2). Furthermore, our analysis results indicated that West Bank-East London area received more rainfall during the Spring (SON) and Summer (DJF) seasons (Figures a and b). This was in line with the works of Engelbrecht et al. (2009) and Dyson (2009), who found out that the model-projected climate change showed an increase in summer rainfall over north-eastern SA. The influence of ENSO events is strongest during the summer rainfall months of December to March when the El Niño/La Niña events have reached maturity (Mason \& Jury, 1997; Nel, 2009). In addition, the southern oscillation influences rainfall variability in the southern hemisphere (Nel, 2009), and this could be as a result of the El Niño/La Niña phenomenon (Hyden \& Sekoli, 2000).

Also, another important finding was that the observed rainfall trends (Figures 2-3 and Table 1) were statistically not significant (at $\mathrm{a}=0.10$ ), and MK test results (Table 1) ranged between $-0.18 \mathrm{~mm}$ and $0.03 \mathrm{~mm}$ at $95 \%$ confidence level for the seasons which suggested that there was both an upward and downward trend in the time series. January was the only month that exhibited a statistically significant linear trend at 5\% and Sen's estimator magnitude of change at a rate of $1.87 \mathrm{~mm}$ (Table 1). In general, rainfall totals from the West Bank-East London area weather station were considerably comparable to BCMM (2004) estimates. In Dyson's (2009) study over Gauteng, October and March months were considered to be the transition months as summer starts in October and ends in March. In addition, March received more rainfall than October. In contrast, West Bank-East London area, October received more rainfall than March for the period under review (1975 to 2011). This contrast in results depicts the necessity for conducting micro studies (station analysis) to offer just-in-time results about a region than relying on generalisation. At the same time, different factors such as location might be the cause for the variation. It was worth noting that the 1970's had been a period where several of rainfall estimates recorded a wetter period for South Africa (Nel \& Sumner, 2008 and references therein). Our results therefore corroborate to results reported in the literature. This long term analysis asserted that rainfall varied over West Bank-East London area across the years. This could be explained by the occurrence of ENSO and El Niño/La Niña events in the region (Jury, 2013; Nel, 2009; Mason \& Jury, 1997). Additionally, our results seemed to suggest that rainfall in this particular area may have been underestimated (in e.g., model simulations) in the past.

\subsubsection{Trend Analysis of Annual Rainfall for Climatic Regimes}

Results showed that the mean annual rainfall estimated during 1975-2011 for West Bank East London area was $1725.3 \mathrm{~mm}$, with the highest and lowest rainfall recorded in $1977(2272.9 \mathrm{~mm})$ and $1975(793.5 \mathrm{~mm})$ (Figure 4) respectively, at $-1.28 \mathrm{~mm}$ decadal change (Table 1 and Table 3). Highest and lowest rainfall monthly mean total's were observed in $1985(109.83 \mathrm{~mm})$ and $2009(46.07 \mathrm{~mm})$ respectively.

The first normal (1975 to 2005) climatic regime indicates that January month trend is statistically significant $(0.321)$ at $95 \%$ confidence level (Table 1$)$. In addition, the monthly annual mean results showed that November received the highest rainfall amount $(117.64 \mathrm{~mm}$ ) (Table 1). No rainfall was recorded in August 1995 and May 
1992 which was an anomaly (Table 3). This anomaly event could be attributed to seasonal variations and oscillation events. For the second climatic normal (1981 to 2011), there is evidence of an increasing trend in rainfall regime though generally not statistically significant e.g. January $(1.305 \mathrm{~mm})$ and December $(1.27 \mathrm{~mm})$ at $95 \%$ confidence level (Table 1). November had the highest monthly mean annual rainfall of $119.07 \mathrm{~mm}$. A closer analysis showed that November received more rainfall in both climatic regimes. It is in the second normal that West Bank-East London area received slightly more rainfall. On the other hand, a decreasing trend between the two climatic regimes at $13.99 \mathrm{~mm}$ was observed. The amount of annual rainfall and its seasonal distribution are crucial factors for understanding the spatial distribution of different ecological units (Bailey, 1998). Therefore, our study results could be of great importance for solving regional water resources problems (Nel \& Sumner, 2006; Nsubuga et al., 2011), and detecting climatic impacts on vegetation.

Overall, the observed rainfall variability could be attributed to several factors. For instance, Washington and Preston (2006) noted that global surface temperatures were capable of generating anomalous wet conditions over southern Africa. Therefore, any fluctuations in global sea surface temperatures could influence rainfall patterns in an area especially given the close proximity of the West Bank-East London area to the Indian Ocean. Furthermore, factors such as ENSO, cyclones and El Niño/La Niña occurrences have been found to influence rainfall in southern Africa (Jury, 2013; Nel 2009; Mason \& Jury, 1997), and consequently could have had an effect on the observed rainfall variability over West Bank-East London area.

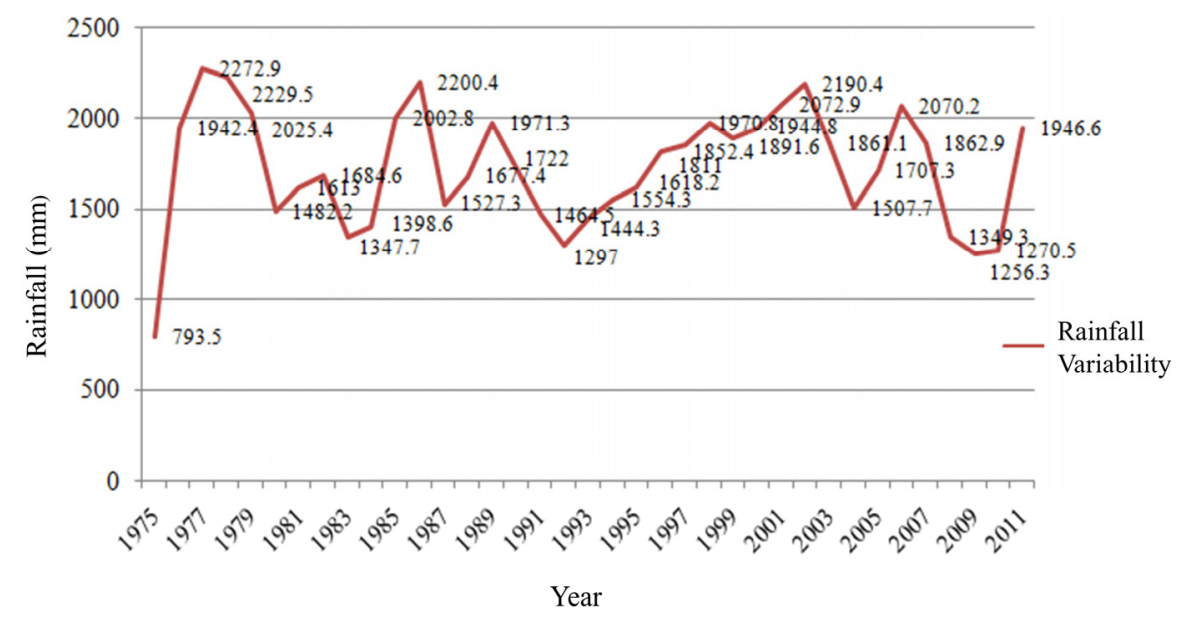

Figure 4. Annual total rainfall trend analysis for West Bank-East London Area 1975-2011 
Table 1. Derived trend values for rainfall and temperature estimates for West Bank-East London Weather Station

\begin{tabular}{|c|c|c|c|c|c|c|c|c|c|c|c|c|c|}
\hline & Jan & Feb & Mar & Apr & May & Jun & Jul & Aug & Sep & Oct & Nov & Dec & Period \\
\hline $\begin{array}{l}\text { Monthly } \\
\text { Rainfall totals } \\
(\mathbf{m m})\end{array}$ & 2.5 & -1.8 & 0.15 & 0.22 & 0.11 & 0.37 & -0.52 & 0.04 & -1.85 & -0.72 & 0.27 & 0.27 & $1975-2011$ \\
\hline $\begin{array}{l}\text { MK Rank stat. } \\
\text { (Tkrit_95\%) }\end{array}$ & 0.32 & -0.16 & 0.02 & 0.14 & 0.04 & -0.14 & -0.09 & -0.07 & -0.24 & -0.12 & 0.01 & 0.11 & 1975-2011 \\
\hline $\begin{array}{l}\text { Magnitude of } \\
\text { change }\end{array}$ & 1.87 & -1.33 & 0.16 & 0.18 & 0.07 & 0.26 & 0.49 & 0.06 & -1.67 & -0.87 & 0.39 & 0.24 & $1975-2011$ \\
\hline $\begin{array}{l}\text { Rainfall trend } \\
\left(1^{\text {st }} \text { normal }\right) \\
(\mathrm{mm})\end{array}$ & 2.62 & -1.33 & 1.13 & 0.19 & -0.45 & -0.91 & -1.04 & -0.45 & -0.75 & -1.49 & 0.49 & 0.05 & $1975-2005$ \\
\hline $\begin{array}{l}\text { MK Rank stat. } \\
\text { (Tkrit_95\%) }\end{array}$ & 0.37 & -0.10 & 0.17 & 0.13 & 0.02 & -0.33 & -0.09 & -0.08 & -0.11 & -0.19 & -0.002 & 0.03 & $1975-2005$ \\
\hline $\begin{array}{l}\text { Magnitude of } \\
\text { change }\end{array}$ & 2.64 & -1.37 & 1.60 & 0.21 & -0.35 & -0.70 & -1.18 & 0.84 & -0.95 & -2.18 & 0.96 & 0.07 & $1975-2005$ \\
\hline $\begin{array}{l}\text { Rainfall trend } \\
\left(2^{\text {nd }} \text { normal }\right) \\
(\mathrm{mm})\end{array}$ & 1.31 & -1.54 & -0.21 & 1.10 & 0.80 & 0.13 & 0.14 & 0.49 & -1.04 & -0.90 & -0.04 & 1.27 & $1981-2011$ \\
\hline $\begin{array}{l}\text { MK Rank stat. } \\
\text { (Tkrit_95\%) }\end{array}$ & 0.22 & -0.19 & -0.11 & 0.19 & 0.12 & -0.17 & 0.01 & 0.01 & -0.17 & -0.19 & 0.02 & 0.24 & $1981-2011$ \\
\hline $\begin{array}{l}\text { Magnitude of } \\
\text { change }\end{array}$ & 1.38 & -1.38 & -0.28 & 0.93 & 0.64 & 0.13 & 0.16 & 0.89 & -1.16 & -1.40 & -0.09 & 1.43 & $1981-2011$ \\
\hline $\begin{array}{l}\text { Mean monthly } \\
\text { Rainfall (mm) }\end{array}$ & 88.7 & 81.6 & 83.9 & 70.0 & 40.3 & 35 & 43.1 & 63.2 & 73.3 & 99.9 & 115.9 & 84.5 & $1975-2011$ \\
\hline $\begin{array}{l}\text { Mean Monthly } \\
\text { Rainfall } \\
\left(1^{\text {st }} \text { normal }\right)(\mathbf{m m})\end{array}$ & 81.3 & 84.8 & 89.5 & 69.3 & 38.1 & 30.9 & 42.6 & 65.77 & 81.1 & 96.6 & 117.6 & 83.4 & $1975-2005$ \\
\hline $\begin{array}{l}\text { Mean Monthly } \\
\text { Rainfall (2 } \mathbf{2}^{\text {nd }} \\
\text { normal)(mm) }\end{array}$ & 96.5 & 78.4 & 86.7 & 67.3 & 37.9 & 36.3 & 38.6 & 59.8 & 66.8 & 99.3 & 119.1 & 80.5 & $1981-2011$ \\
\hline $\begin{array}{l}\text { Std of } \\
\text { Rainfall(mm) }\end{array}$ & 52.1 & 50.1 & 66.7 & 50.6 & 40.5 & 44.8 & 60.7 & 88.2 & 60.5 & 77.4 & 90.9 & 58.0 & $1975-2011$ \\
\hline $\begin{array}{l}\text { Average Temp } \\
\left({ }^{\circ} \mathrm{C}\right)\end{array}$ & 2.71 & 4.59 & 2.87 & 1.94 & 3.66 & 2.52 & 1.50 & 3.67 & 4.01 & 4.98 & 2.40 & 1.43 & $1975-2011$ \\
\hline $\begin{array}{l}\text { MK Rank stat. } \\
\text { (Tkrit_95\%) }\end{array}$ & 0.23 & 0.39 & 0.29 & 0.17 & 0.39 & 0.22 & 0.14 & 0.34 & 0.31 & 0.41 & 0.20 & 0.05 & $1975-2011$ \\
\hline $\begin{array}{l}\text { Magnitude of } \\
\text { change }\end{array}$ & 0.02 & 0.39 & 0.04 & 0.23 & 0.05 & 0.03 & 0.02 & 0.04 & 0.04 & 0.05 & 0.03 & 0.02 & $1975-2011$ \\
\hline $\begin{array}{l}\text { Max Temp } \\
\text { trend }\left(1^{\text {st }}\right. \\
\text { normal) }{ }^{\circ} \mathrm{C}\end{array}$ & 0.71 & 0.35 & 1.34 & 1.06 & 0.32 & 0.90 & -0.82 & 0.82 & 0.56 & 0.59 & 3.62 & 1.56 & $1975-2005$ \\
\hline $\begin{array}{l}\text { MK Rank stat. } \\
\text { (Tkrit_95\%) }\end{array}$ & 0.08 & 0.05 & 0.18 & 0.12 & -0.04 & 0.09 & -0.13 & 0.11 & 0.03 & 0.10 & 0.29 & 0.16 & $1975-2005$ \\
\hline $\begin{array}{l}\text { Magnitude. of } \\
\text { change }\end{array}$ & 0.03 & 0.01 & 0.06 & 0.07 & 0.01 & 0.03 & -0.04 & 0.03 & 0.04 & 0.05 & 0.19 & 0.05 & $1975-2005$ \\
\hline $\begin{array}{l}\text { Max Temp } \\
\text { trend }\left(2^{\text {nd }}\right. \\
\text { normal) }{ }^{\circ} \mathrm{C}\end{array}$ & 1.38 & 1.97 & 1.04 & 0.47 & -1.42 & 1.09 & -0.78 & 1.24 & -0.83 & 0.22 & 1.25 & -0.93 & $1981-2011$ \\
\hline $\begin{array}{l}\text { MK Rank stat. } \\
\text { (Tkrit_95\%) }\end{array}$ & 0.14 & 0.19 & 0.17 & 0.06 & -0.24 & 0.06 & -0.09 & 0.07 & -0.08 & -0.01 & 0.04 & -0.11 & $1981-2011$ \\
\hline $\begin{array}{l}\text { Magnitude of } \\
\text { change }\end{array}$ & 0.06 & 0.05 & 0.05 & 0.03 & -0.05 & 0.04 & -0.04 & 0.05 & -0.06 & 0.02 & 0.08 & -0.03 & 1981-2011 \\
\hline
\end{tabular}




\begin{tabular}{|c|c|c|c|c|c|c|c|c|c|c|c|c|c|}
\hline $\begin{array}{l}\text { Max Temp } \\
\text { trend }\left({ }^{\circ} \mathrm{C}\right)\end{array}$ & 1.33 & 1.17 & 1.32 & 0.94 & -0.41 & 0.98 & -0.82 & 0.93 & 0.91 & -0.02 & 1.85 & 0.10 & $1975-2011$ \\
\hline $\begin{array}{l}\text { MK Rank stat. } \\
\text { (Tkrit_95\%) }\end{array}$ & 0.12 & 0.11 & 0.18 & 0.11 & -0.11 & 0.05 & -0.08 & 0.04 & 0.08 & 0.01 & 0.11 & 0.000 & $1975-2011$ \\
\hline $\begin{array}{l}\text { Magnitude of } \\
\text { change }\end{array}$ & 0.05 & 0.03 & 0.05 & 0.05 & -0.01 & 0.02 & -0.03 & 0.03 & 0.05 & -0.001 & 0.08 & -0.003 & $1975-2011$ \\
\hline $\begin{array}{l}\text { Min Temp trend } \\
\left({ }^{\circ} \mathrm{C}\right)\end{array}$ & -0.21 & 2.42 & 2.30 & -1.69 & 1.58 & 1.46 & 0.05 & 0.19 & 1.32 & 1.17 & 0.20 & -0.91 & $1975-2011$ \\
\hline $\begin{array}{l}\text { MK Rank stat. } \\
\text { (Tkrit_95\%) }\end{array}$ & -0.07 & 0.22 & 0.21 & -0.20 & 0.18 & 0.14 & -0.02 & -0.01 & 0.14 & 0.14 & -0.03 & -0.10 & $1975-2011$ \\
\hline $\begin{array}{l}\text { Magnitude of } \\
\text { change }\end{array}$ & -0.003 & 0.06 & 0.04 & -0.04 & 0.04 & 0.04 & 0.001 & 0.01 & 0.03 & 0.02 & 0.01 & -0.02 & $1975-2011$ \\
\hline $\begin{array}{l}\text { Min Temp trend } \\
\left(1^{\text {st }} \text { normal }\right){ }^{\circ} \mathrm{C}\end{array}$ & 0.20 & 1.03 & 0.46 & -0.51 & 2.20 & 2.71 & 0.21 & 0.40 & 1.22 & 3.07 & -0.21 & 1.32 & $1975-2005$ \\
\hline $\begin{array}{l}\text { MK Rank stat. } \\
\text { (Tkrit_95\%) }\end{array}$ & -0.02 & 0.03 & 0.04 & -0.06 & 0.22 & 0.31 & 0.02 & 0.02 & 0.09 & 0.27 & -0.09 & 0.11 & $1975-2005$ \\
\hline $\begin{array}{l}\text { Magnitude of } \\
\text { change }\end{array}$ & 0.004 & 0.04 & 0.01 & -0.01 & 0.07 & 0.10 & 0.01 & 0.01 & 0.03 & 0.05 & -0.01 & 0.03 & $1975-2005$ \\
\hline $\begin{array}{l}\text { Min Temp trend } \\
\left(2^{\text {nd }} \text { normal }\right){ }^{\circ} \mathrm{C}\end{array}$ & 1.38 & 1.97 & 1.04 & 0.47 & -1.42 & 1.09 & -0.78 & 1.24 & -0.83 & 0.22 & 1.25 & -0.925 & $1981-2011$ \\
\hline
\end{tabular}

NB: Bold values show linear trends that are statistically significant at 5\%.

\subsection{Temperature Changes and Trends}

Temperature time series of West Bank-East London area were also investigated for temporal trends (monthly, seasonal and annual) to provide a micro scenario for 1975 to 2011 temperature variability. Understanding of micro- temperature trends was a key aspect in achieving the study aim.

\subsubsection{Monthly and Seasonal Temperature Trend Analysis}

A detailed analysis showed that February had the highest mean monthly temperature of $21.8^{\circ} \mathrm{C}$ and July with the lowest $12.6{ }^{\circ} \mathrm{C}$ (Figure 5). Mean monthly annual highest and lowest temperatures were observed in December $1999\left(23.7^{\circ} \mathrm{C}\right)$ and July $2011\left(11.1^{\circ} \mathrm{C}\right)$ respectively. However, the lowest of the maximum temperatures and highest of the minimum temperature were recorded in June $2009\left(14.5^{\circ} \mathrm{C}\right)$ and February $1976\left(20.6{ }^{\circ} \mathrm{C}\right)$ respectively. It is worth noting that only 3 months (April, July and December) for the entire study period had trends which are not statistically significant but were positive. This assertion could be compared with Kruger and Shongwe (2004) that there was a general pre-dominating positive trend in temperature although not always significant for the period 1960 to 2003 over SA. Therefore, these results are consistent with those of Huges and Balling (1996), and Kruger and Shongwe (2004).

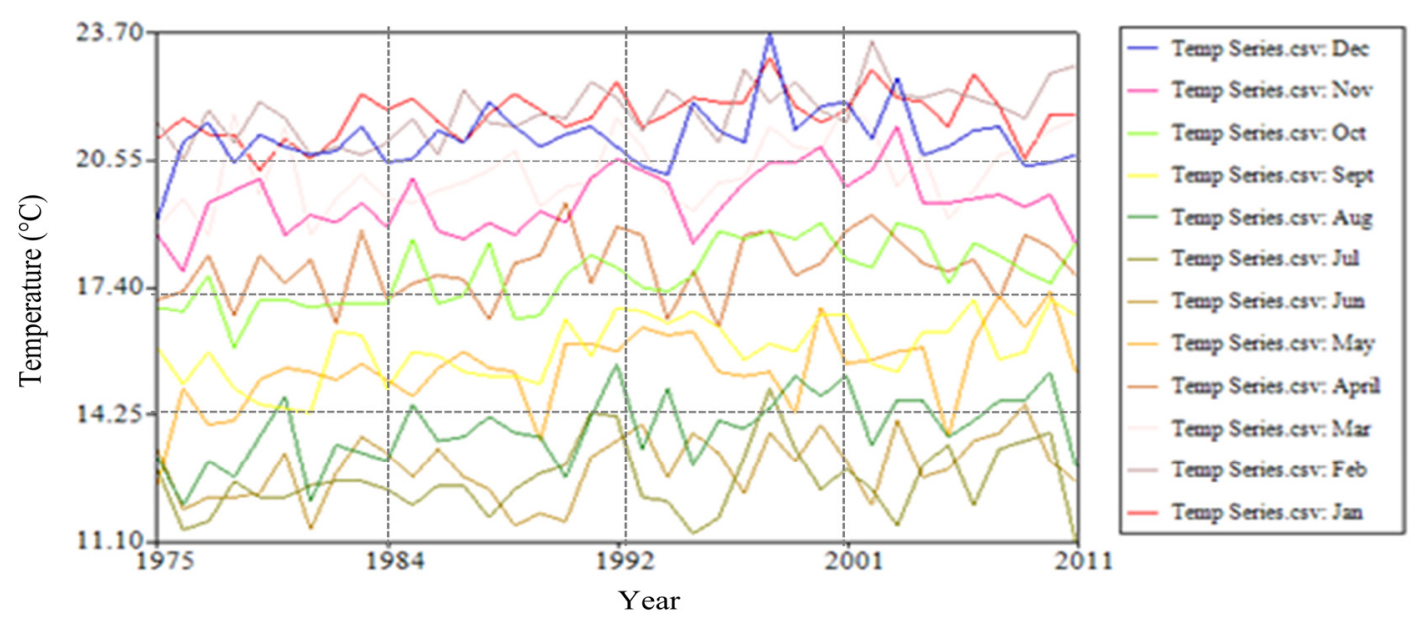

Figure 5. Analysis of mean annual extreme temperature from 1975 to 2011 period in West Bank-East London 
Seasonal trends for all the mean maximum temperature (Tmax) data showed no statistically significant trend (at $\mathrm{a}=0.10$ ) (Figures 6 to 9 , and Tables 1 and 2). On the other hand, mean minimum temperature (Tmin), for autumn reveal an increasing statistically significant trend at a $<0.1$ (see Table 2). At the same time, the season with the highest mean Tmax trend is autumn, and that with the lowest trend is spring (Table 2). This is consistent with both Kruger and Shongwe (2004), and Muhlenbruch-Tegen (1992) findings for 1960 to 2003 and 1949 to 1989 periods respectively. In general, DJF has the highest average annual seasonal temperature $\left(25.8^{\circ} \mathrm{C}\right)$, while JJA $\left(22.8^{\circ} \mathrm{C}\right)$ experiences the least. The overall maximum temperature trend follows the seasonal distributions for the study period and all the seasons show a positive trend. However, our study has not established the causes of the differences in the trend and means for monthly temperature trends; this could probably be explained further with the aid of a general circulation models.
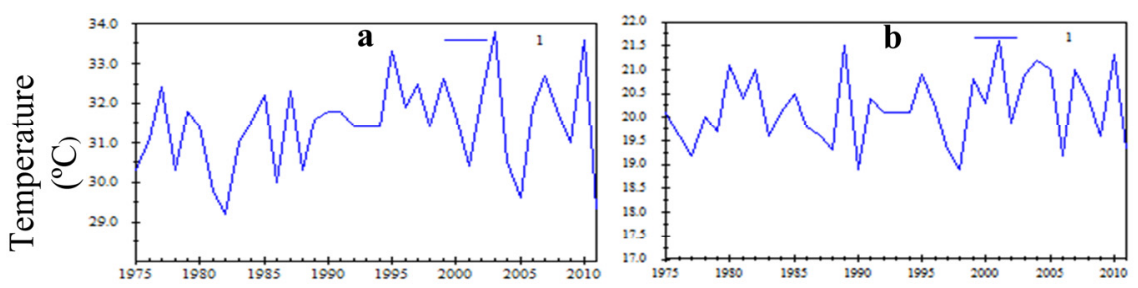

Year

Figure 6. DJF mean temperature trend analysis, a) Maximum and b) Minimum from 1975-2011
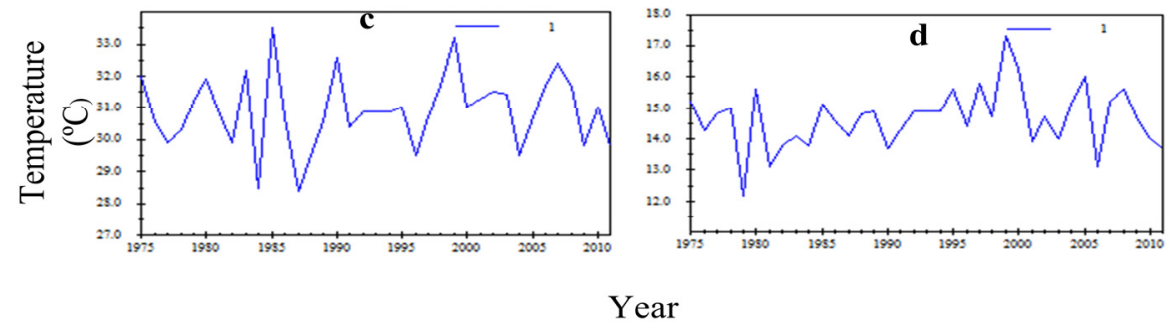

Figure 7. JJA mean temperature trend analysis, c) Maximum and d) Minimum from 1975-2011
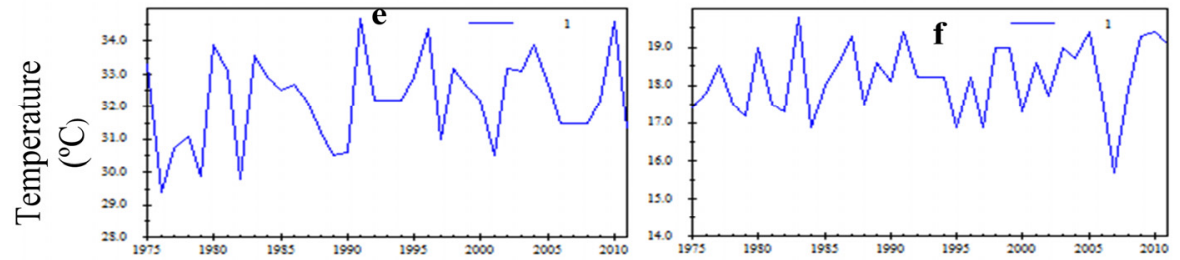

Year

Figure 8. MAM mean temperature trend analysis, e) Maximum and f) Minimum from 1975-2011
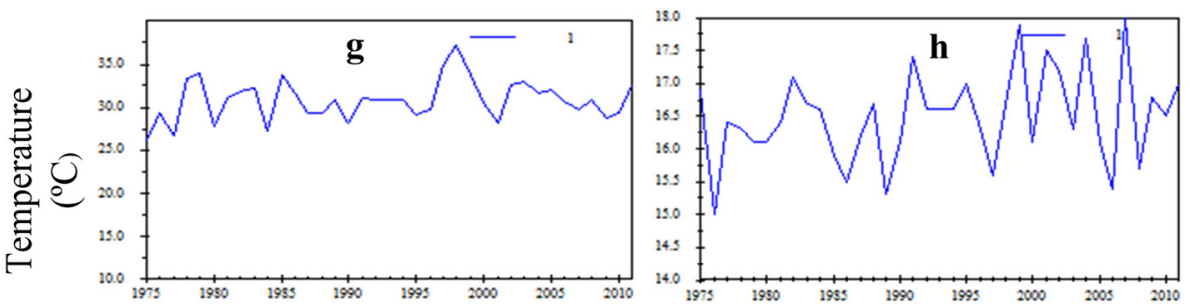

Year

Figure 9. SON mean temperature trend analysis, g) Maximum and h) Minimum from 1975-2011 
Table 2. West Bank-East London mean seasonal temperature statistics for 1975 to 2011

\begin{tabular}{ccccccccc}
\hline \multirow{2}{*}{ Season } & \multicolumn{2}{c}{ DJF - Summer } & \multicolumn{2}{c}{ MAM - Autumn } & \multicolumn{2}{c}{ JJA - Winter } & \multicolumn{2}{c}{ SON - Spring } \\
\cline { 2 - 8 } & Tmax & Tmin & Tmax & Tmin & Tmax & Tmin & Tmax & Tmin \\
\hline Mean & 31.432 & 20.186 & $\mathbf{3 2 . 1 8 6}$ & 18.181 & 30.908 & 14.654 & 30.832 & 16.495 \\
SD & 1.124 & 0.745 & 1.36 & 0.917 & 1.144 & 0.963 & 2.35 & 0.706 \\
Z-Statistic & 1.57 & 1.164 & 0.785 & $\mathbf{1 . 6 8 7}$ & 0.824 & 0.863 & 0.745 & 1.399 \\
\hline
\end{tabular}

Data shows statistically significant trend (at a $<0.1)$ with an increasing trend.

\subsubsection{Annual Temperature and Climatic Regime Trend Analysis}

Both maximum and minimum annual mean temperature trend for 1975 to 2011 data showed statistically significant increasing trend at a $<0.05$. This finding conforms to what Hulme et al. (2001) and Nsubuga et al. (2011) also observed i.e. warming trends in Africa, and at Namulonge in Uganda (1947-2009) respectively. Further analysis, revealed that highest mean temperature was recorded for Tmax in August $\left(32.6^{\circ} \mathrm{C}\right)$ and $\mathrm{Tmin}$ in February $\left(20.6{ }^{\circ} \mathrm{C}\right)$, and the lowest was in June $\left(29.7^{\circ} \mathrm{C}\right)$ and July $\left(14.7^{\circ} \mathrm{C}\right)$ respectively. Furthermore, it was only the max-Tmin trend that showed a statistically significant trend at -3.022 and a decadal change of $-3.126^{\circ} \mathrm{C}$. On the other hand, both the MK test results were negative in the range of -0.212 and $-0.394{ }^{\circ} \mathrm{C}$. It can be noted that this station data, in a broad sense showed increases and decreases in trend from one month to another, as well as months of minimum and maximum trend based on the data from the two regimes.

Majority of the monthly trends for maximum temperature in first normal (1975-2005) are not statistically significant except November which shows an increasing trend at $\mathrm{t}=3.615$, and $1.944{ }^{\circ} \mathrm{C}$ per decade and MK test result of 0.286 (Table 1). On the other hand, in the second normal (1981-2011) no month exhibited any statistically significant trend (Table 1). It is important to note that August had the highest annual monthly mean $32.52{ }^{\circ} \mathrm{C}$ (1st normal) and $32.6{ }^{\circ} \mathrm{C}$ (2nd normal). This depicted a slight increase in the annual monthly mean temperature of $0.08{ }^{\circ} \mathrm{C}$. Generally, most of the months across both climatic regimes showed a positive but non-significant trend except for June (1st normal, 1975-2005), and May, July, September, and December (2nd normal, 1981-2011) (Table 1).

In addition, the minimum temperature trends for the months of May, June, and October during the first normal climatic regime exhibited a statistically significant positive trend (Table 1) while no month in the second normal climatic regime trend was statistically significant. Annual mean monthly temperature analysis revealed that February $\left(20.47^{\circ} \mathrm{C}\right)$ and August $\left(32.6^{\circ} \mathrm{C}\right)$ months had the highest mean in the $1^{\text {st }}$ normal $(1975-2005)$ and $2^{\text {nd }}$ normal (1981-2011) respectively. The lowest minimum temperature was recorded in July $\left(14.5^{\circ} \mathrm{C}\right)$ and June $\left(29.7^{\circ} \mathrm{C}\right)$. Generally minimum temperatures are on the rise in the West Bank - East London area. The maximum temperature during the first and second normals, and minimum temperature second normal climatic regimes depicted that October of $1997\left(43.11^{\circ} \mathrm{C}\right)$ had the highest and June $1996\left(33.0^{\circ} \mathrm{C}\right)$ had the least mean temperature.

Consequently, the noted global average temperature increase by $0.6 \pm 0.2{ }^{\circ} \mathrm{C}$ over the last century and the projected increase of 1.4 to $5.8{ }^{\circ} \mathrm{C}$ (IPCC, 2007) could explain the observed temperature rise over West Bank-East London area. Also Ekpoh and Nsa (2011) have argued that anthropogenic climate change may as well increase the likelihood of such events occurring (e.g. increase in temperature). In Addition, Collins (2011) also highlighted that only global and regional climate models with anthropogenic forcing can perhaps explain temperature warming due to human activities. Furthermore, Kruger and Shongwe (2004) noted that increasing temperature could be attributed to urbanisation and industrialisation among others, taking place in some parts of SA. Overall, these factors could account for the variability in temperature observed over West Bank-East London area.

\subsection{Seasonality Rainfall and Temperature Relationship Analysis}

To further unpack climate variability, rainfall and temperature parameters were concurrently explored based on seasonal behaviour. Notably, Barley (1998 in Nel, 2009) argues that the amount of annual rainfall and its seasonal distribution are crucial factors for understanding the spatial distribution of different ecological units. Therefore, cross-tabulation analysis was adopted to explore pair wise relationships between seasons which enabled the detection of temporal similarities among trends between rainfall and temperature (see Figure 10). 


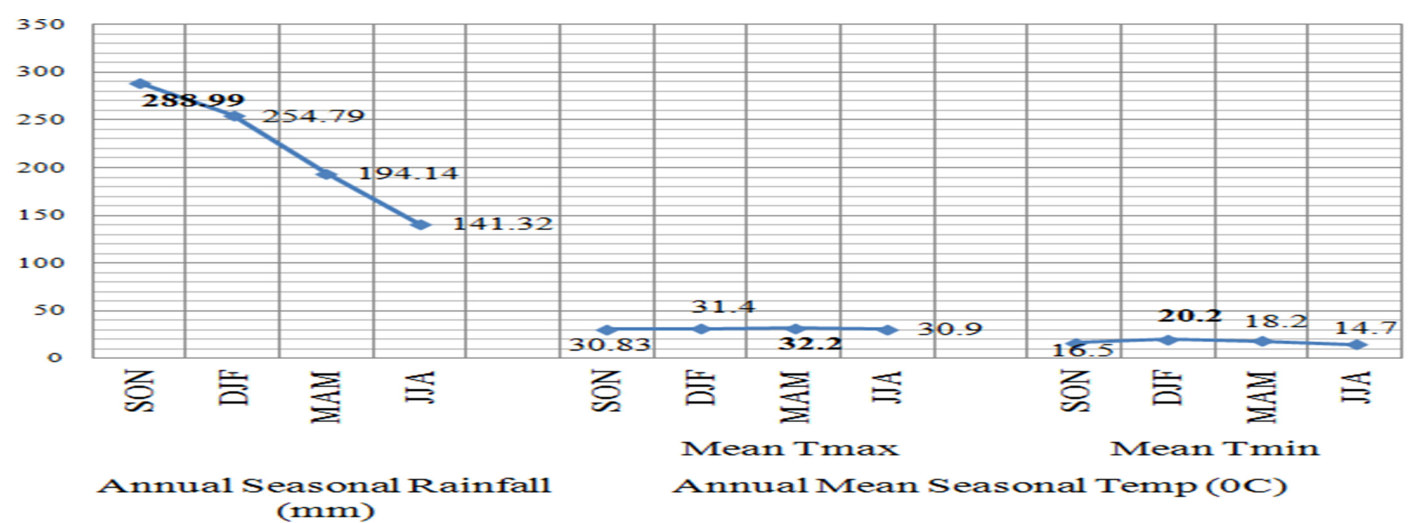

Figure 10. Seasonal trend relationship between rainfall and temperature for 1975-2011

Generally, DJF season observed a positive seasonal relationship between rainfall and temperature for the study period especially for the annual rainfall and mean-Tmin annual mean temperature (Figure 10). This is in line with Van Heerden et al. (1988) results, which revealed a strong relationship between summer monthly SOI values and corresponding summer monthly rainfall in South Africa. Also consistent with Nel and Sumner (2008) study in the Drankensburg, winter rainfall was the lowest $141.32 \mathrm{~mm}$ at $22.8{ }^{\circ} \mathrm{C}$ average temperature. On the other hand, autumn (MAM) exhibited the highest mean temperature which is consistent with previous work by Kruger and Shongwe (2004), and Muhlenbruch-Tegen (1992). In addition, 1990-1999 (Table 3 and Figures 2 - 9) is a period that exhibited many extreme events (highest and lowest means) across the data set for the period of study. These results are comparable with Mason et al. (1999) observation that between 1931 and 1990, the intensity of extreme events has increased significantly over SA. In addition, SON season received the highest rainfall $\left(288.99 \mathrm{~mm}\right.$ ) with an average temperature of $23.7^{\circ} \mathrm{C}$, while JJA recorded the lowest rainfall and temperature for the study period. The seasonal variation of rainfall and temperature was between $288.99 \mathrm{~mm}$ and $141.32 \mathrm{~mm}$, and $32.2^{\circ} \mathrm{C}$ and $14.7^{\circ} \mathrm{C}$ (Figure 10) respectively.

Table 3. Extreme events for analysed trends as per the occurrences between 1975 and 2011

\begin{tabular}{cccc}
\hline Year category & $\begin{array}{c}\text { Number of years with highest mean } \\
\text { events }\end{array}$ & $\begin{array}{c}\text { Number of years with lowest } \\
\text { mean events }\end{array}$ & Total \\
\hline $1975-1979$ & 13 & 29 & 42 \\
$1980-1989$ & 34 & 32 & 66 \\
$1990-1999$ & 47 & 41 & 88 \\
$2000-2011$ & 48 & 32 & 80 \\
\hline
\end{tabular}

\section{Conclusions}

This study analysed climatic variability trends for the West Bank - East London area over the last 36 years using the West Bank weather station rainfall and temperature data. Although, non-parametric tests have some limitations, they provided a basic way of analysing CVC trends in this study, and these techniques have also been adopted in a number of previous studies (e.g. Nsubuga et al., 2011, 2013; Jain et al., 2012; Kizza et al., 2009) for the same purpose. As such, this study provided a clear understanding of the temporal changing patterns in rainfall and temperature at local level. Studies of climate change and variability at local level are important for climate change impact studies: which is crucial in planning and management of natural resources among others. At the same time, potential impacts that any changes in climate could have on the West Bank's ecologically sensitive vegetation can be deduced. As noted elsewhere, climate variability could affect other sectors (See, Midgley et al., 2007).

The research findings corroborate to other previous study findings conducted in other parts of South Africa (e.g. Tshiala et al., 2011; Nel, 2009; Kruger \& Shongwe, 2004; Hughes \& Balling, 1996; Muhlenbruch-Tegen, 1992). Historical records indicated that inter-annual rainfall variability over South Africa was increasing (Mason, 1996), but at the West Bank station, seasonal and annual rainfall show a non-statistically significant trend (at $\mathrm{a}=0.10)$. 
Mean annual rainfall was highly seasonal with $73.7 \%$ of the total rainfall measured during September to March. It is important to note that most of the rainfall was received during the summer period. This could be attributed to established fact that southern African summer rainfall is significantly influenced by ENSO (Nel, 2009; Humle et al., 2001; King'uyu et al., 2000; Hyden \& Sekoli, 2000; Klopper et al., 1998; Mason \& Jury, 1997; Van Heerden et al., 1988) with La Niña episodes bringing wet conditions in the region. August 1995 and 2002 showed the lowest and highest total rainfall of 0.00 and $493.8 \mathrm{~mm}$ respectively. Seasonal and annual rainfall showed no statistically significant trend (at $\mathrm{a}=0.10$ ).

Maximum and minimum annual mean temperature data show statistically significant (at a $<0.05$ ) increasing trend at 95\% confidence level. These results are consistent with Collins (2011) which indicated that rapid warming from 1970 onward was witnessed in SA. It was only MAM season (autumn) for the mean minimum temperature (Tmin) data set that revealed a statistically significant trend $($ at a $<0.1$ ) with an increasing trend. In addition, it was the season with the highest MK test value (1.687; see e.g., Table 2). Autumn had the highest mean maximum temperature which is also consistent with Kruger and Shongwe (2004), and Muhlenbruch-Tegen (1992) studies. Also the period 1990-1999 predominantly experienced numerous extreme events for entire study period (see, Table 3). Generally, the seasonal trends showed substantial variability (increasing and decreasing) across the months and years. Therefore, CVC likely occur owing to natural variability of the climate and or may be attributed to anthropogenic processes. The work reported in this study has important ecological applications because the amount of annual rainfall and temperature, and their seasonal distribution are crucial factors for understanding the spatial distribution of different ecological units (Bailey, 1998). Indeed, this could affect West Bank vegetation especially the ecologically sensitive species (Lubke, 1984; BCMM, 2004), for instance by causing stress in the vegetation. This study suggests that further research into the underlying local factors influencing the climate of the area, causes for the differences in monthly mean temperature, actual effects of ENSO on rainfall totals and the influence of Indian Ocean over West Bank-East London area need to be conducted. At the same time aspects of the impacts of urbanisation and global warming on the micro temperature also require further exploration.

\section{Acknowledgements}

This research was possible due to the provision of free data by the South African Weather services with sincere appreciation to Elsa de Jager and Joe Matsapola of that institution, and the financial support from the University of Pretoria and IPCC.

\section{References}

Akpalu, W., Hassan, R. M., \& Ringler, C. (2008). Climate variability and maize yield in South Africa. Environment and Production Technology Division. IFPRI Paper, 843.

Arora, M., Goel, N. K., \& Singh, P. (2005). Evaluation of temperature trends over India/Evaluation de tendances de température en Inde. Hydrological sciences journal, 50(1). http://dx.doi.org/10.1623/hysj.50.1.81.56330

Bailey, R. G. (1998). Ecoregions: The ecosystem geography of the oceans and continents. Springer, New York.

Buffalo City Metropolitan Municipality-BCMM, (2004). West Bank local spatial development framework. October, 2004.

Chiew, F., \& Siriwardena, L. (2005). Trend: trend/change detection. CRC for Catchment Software Hydrology, Australia. Retrieved from www.toolkit.net.au/trend

Christensen, J. H., Hewitson, B., Busuioc, A., Chen, A., Gao, X., Held, R., ... Dethloff, K. (2007). Regional climate projections. In S. Solomon, D. Qin, M. Manning, Z. Chen, M, Marquis, K. B. Averyt, M. Tignor, \& H. L.Miller (Eds.), Climate Change 2007: The Physical Science Basis. Contribution of Working Group I to the Fourth Assessment Report of the Intergovernmental Panel on Climate Change. Cambridge University Press, UK and New York, USA.

Coastal and Resource Management, (1994). Environmental assessment West Bank development project. Report No. 001/94.

Collins, J. M. (2011). Temperature variability over Africa. Journal of Climate, 24, 3649-3666. http://dx.doi.org/10.1175/2011JCLI3753.1

Council for Scientific and Industrial Research-CSIR. (2011). Understanding climate variability and change. Retrieved from http://climatechange.csir.co.za/?p=205Understanding climate variability and change Climate Change

Dyson, L. L. (2009). Heavy daily-rainfall characteristics over the Gauteng Province. Water SA, 35(5). 
http://dx.doi.org/10.4314/wsa.v35i5.49188

Easterling, D. R., Alexander, L. V., Mokssit, A., \& Detemmerman, V. (2003). CCI/CLIVAR Workshop to develop priority climate indicies. Meeting summaries. American Meteorological Society. BAMS 1403-1407.

Ekpoh, I. J., \& Nsa, E. (2011). Extreme climatic variability in North-western Nigeria: an analysis of rainfall trends and patterns. Journal of Geography and Geology, 3(1). http://dx.doi.org/10.5539/jgg.v3n1p51

El Kenawy, A. M., López-Moreno, J. I., Vicente-Serrano, S. M., \& Mekld, M. S. (2009). Temperature trends in Libya over the second half of the 20th century. Theoretical and applied climatology, 98(1-2), 1-8. http://dx.doi.org/10.1007/s00704-008-0089-2

Engelbrecht, F. A., McGregor, J. L., \& Engelbrecht, C. J. (2009). Dynamics of the Conformal - Cubic Atmospheric Model projected climate - change signal over southern Africa. International Journal of Climatology, 29(7), 1013-1033. http://dx.doi.org/10.1002/joc.1742

Fernandez-Illescas, C. P., \& Rodriguez-Iturbe, I. (2004). The impact of interannual rainfall variability on the spatial and temporal patterns of vegetation in a water-limited ecosystem. Advances in Water Resources, 27(1), 83-95. http://dx.doi.org/10.1016/j.advwatres.2003.05.001

Helmes, T. C., Deckard, E., Goos, R. J., \& Enz, J. W. (1996). Soil moisture, temperature and drying influence on $\begin{array}{lllll}\text { soya bean } \quad \text { emergence. } & \text { Agricultural }\end{array}$ http://dx.doi.org/10.1002/(SICI)1097-0088(199608)16:8<935::AID-JOC64>3.0.CO;2-V

Hewitson, B. C., \& Crane, R. G. (2006). Consensus between GCM climate change projections with empirical downscaling: precipitation downscaling over South Africa. International Journal of Climatology. 26, 1315-1337. http://dx.doi.org/10.1002/joc.1314

Hughes, W. S., \& Balling, R. C. (1996). Urban influences on South African temperature trends. International $\begin{array}{llll}\text { Journal of Climatology, } & 16, & 935-940 .\end{array}$ http://dx.doi.org/10.1002/(SICI)1097-0088(199608)16:8<935::AID-JOC64>3.0.CO;2-V

Hulme, M., Doherty, R., Ngara., T., New, M., \& Lister, D. (2001). African climate change: 1900-2100. Climate Research, 17, 145-168. http://dx.doi.org/10.3354/cr017145

Hyd'en, L., \& Sekoli T. (2000). Possibilities to forecast early summer rainfall in the Lesotho Lowlands from the El Niño/Southern Oscillation. Water SA, 26, 83-90.

Intergovernmental Panel on Climate Change (IPCC). (2007). Climate change 2007-the physical science contribution of working group 1 to the fourth assessment report.

Jain, S. K., \& Kumar, V. (2012a). Trend analysis of rainfall and temperature data for India. Current Science, 102(1).

Jain, S. K., Kumar, V., \& Saharia, M. (2012b). Analysis of rainfall and temperature trends in northeast India. International Journal of Climatology.

Jones, P. D. (1994). Hemispheric surface air temperature variations: a reanalysis and an update to 1993. Journal of Climate, 7(11), 1794-1802. http://dx.doi.org/10.1175/1520-0442(1994)007<1794:HSATVA>2.0.CO;2

Jury, M. R. (2013). Climate trends in Southern Africa. South African Journal of Science. http://dx.doi.org/10.1590/sajs.2013/980

Kendall, M. G. (1975). Rank correlation methods. London, UK: Charles Griffin.

King'Uyu, S. M., Ogallo, L. A., \& Anyamba, E. K. (2000). Recent trends of minimum and maximum surface temperatures over Eastern Africa. Journal of Climate, 13(16), 2876-2886. http://dx.doi.org/10.1175/1520-0442(2000)013<2876:RTOMAM >2.0.CO;2

Kizza, M., Rodhe, A., Xu, C. Y., Ntale, H. K., \& Halldin, S. (2009). Temporal rainfall variability in the Lake Victoria Basin in East Africa during the twentieth century. Theoretical and applied climatology, 98(1-2), 119-135. http://dx.doi.org/10.1007/s00704-008-0093-6

Klopper, E., Landman, W. A., \& Van Heerden, J. (1998). The predictability of seasonal maximum temperature in South Africa. International Journal of Climatology, 18(7), 741-758. http://dx.doi.org/10.1002/(SICI)1097-0088(19980615)18:7<741::AID-JOC279>3.0.CO;2-B

Krishnamurthy, V., \& Shukla, J. (2000). Intraseasonal and interannual variability of rainfall over India. Journal of Climate, 13(24), 4366-4377. http://dx.doi.org/10.1175/1520-0442(2000)013<0001:IAIVOR>2.0.CO;2 
Kruger, A. C., \& Shongwe, S. (2004).Temperature trends in South Africa:1960-2003. International Journal of Climatology, 24, 1929-1945. http://dx.doi.org/10.1002/joc.1096

Laburn, P. (2011). South Africa and climate change: an ambitious target that needs an action plan! Retrieved from http://www.petelaburn.com/wp-content/uploads/2011/02/South-Africa-and-Climate-Change.pdf

Longobardi, A., \& Villani, P. (2010). Trend analysis of annual and seasonal rainfall time series in the Mediterranean area. International journal of Climatology, 30(10), 1538-1546.

López-Moreno, J. I., Vicente-Serrano, S. M., Angulo-Martínez, M., Beguería, S., \& Kenawy, A. (2010). Trends in daily precipitation on the northeastern Iberian Peninsula, 1955-2006. International journal of Climatology, 30(7), 1026-1041.

Lubke, R. A. (1984). Comments on the ecology and the vegetation in the development proposals of the West Bank, East London.

Lubke, R. A., Everard, D. A., \& Jackson, S. (1986). The biomes of the Eastern Cape with emphasis on their conservation. Bothalia, 16, 251-261.

Mann, H. B. (1945). Nonparametric tests against trend. Econometrica: Journal of the Econometric Society, 245-259. http://dx.doi.org/10.2307/1907187

Mason, S. J. (1996). Climatic change over the Lowveld of South Africa. Climatic change, 32(1), 35-54. http://dx.doi.org/10.1007/BF00141277

Mason, S. J., \& Jury, M. R. (1997). Climatic variability and change over southern Africa: A reflection on underlying processes. Prog. Phys. Geography, 21, 23-51. http://dx.doi.org/10.1177/030913339702100103

Mason, S. J., Waylen, P. R., Mimmack, G. M., Rajaratnam, B., \& Harrison, J. M. (1999). Changes in extreme rainfall events in South Africa. Climatic Change, 41(2), 249-257. http://dx.doi.org/10.1023/A:1005450924499

Midgley, G. F., Chapman, R. A., Hewitson, B., Johnston, P., De Wit, M., Ziervogel, G., ... \& Forsyth, G. G. (2005). A status quo, vulnerability and adaptation assessment of the physical and socio-economic effects of climate change in the Western Cape. Report to the Western Cape Government, Cape Town, South Africa. CSIR Report No. ENV-SC, 73. In P. Mukheibi \& D. Sparks (Eds), Climate Variability, climate change and water resource strategies for small municipalities. Report to the Water Research Commission. WRC project: $\mathrm{K} 5 / 1500$.

Muhlenbruch-Tegen, A. (1992). Long-term surface temperature variations in South Africa. South African Journal of Science, 88, 197-205.

Mukheibir, P., \& Sparks, D. (2005). Climate Variability, climate change and water resource strategies for small municipalities. Report to the Water Research Commission. WRC project: K5/1500, University of Cape Town.

Nel, W. (2009). Rainfall trends in the KwaZulu-Natal Drakensberg region of South Africa during the twentieth century. International Journal of Climatology, 29, 1634-1641. http://dx.doi.org/10.1002/joc.1814

Nel, W., \& Sumner P. D. (2006) Trends in rainfall total and variability (1970-2000) along the KwaZulu-Natal Drakensberg foothills. South African Geographical Journal, 88(2), 130-137. http://dx.doi.org/10.1080/03736245.2006.9713855

Nel, W., \& Sumner, P. D. (2008). Rainfall and temperature attributes on the Lesotho-Drankensberg escarpment edge, South Africa. Journal Compilation Swedish Society for Anthropology and Geography.

Ngongondo, C., Xu, C. Y., Gottschalk, L., \& Alemaw, B. (2011). Evaluation of spatial and temporal characteristics of rainfall in Malawi: a case of data scarce region. Theoretical and applied climatology, 106(1-2), 79-93. http://dx.doi.org/10.1007/s00704-011-0413-0

Nsubuga, F. N. W., Olwoch, J. M., Rautenbach, C. J. deW., \& Botai, O. J. (2013). Analysis of mid-twentieth century rainfall trends and variability over south-western Uganda. Theoretical Applied Climatology. http://dx.doi.org/10.1007/s00704-013-0864-6

Olwoch, J. M., \& Rautenbach, C. D. W. (2011). Climatic Trends at Namulonge in Uganda: 1947-2009. Journal of Geography and Geology, 3(1), 119. http://dx.doi.org/10.5539/jgg.v3n1p119

Schulze, R. E. (2005). Looking into the future: Why research impacts of possible climate change on hydrological responses in Southern Africa. Climate Change and Water Resources in Southern Africa: Studies on 
Scenarios, Impacts, Vulnerabilities and Adaptation. WRC Report, (1430/1), 05.

Schulze, R. E., \& Maharaj, M. (2004). Development of a database of gridded daily temperatures for SouthernAfrica. Water Research Commission. WRC Report No. 1156/2/04. Pretoria, South Africa.

Sen, P. K. (1968). Estimates of the regression coefficient based on Kendall's tau. Journal of the American Statistical Association, 63, 1379-1389. http://dx.doi.org/10.1080/01621459.1968.10480934

Štěpánek, P. (2008). AnClim-software for time series analysis: Dept. of Geography, Fac. of Natural Sciences, MU, Brno. 1.47 MB. Retrieved from http://www.climahom.eu/AnClim.html

Tshiala, M. F., Olwoch, J. M., \& Engelbrecht, F. A. (2011). Analysis of temperature trends over Limpopo Province, South Africa. Journal of Geography and Geology, 3(1). http://dx.doi.org/10.5539/jgg.v3n1p13

Tyson, P. D. (1986). Climatic Change and Variability in Southern Africa (p. 220). Cape Town: Oxford University Press.

Tyson, P. D., Cooper, G. R. J., \& McCarthy, T. S. (2002). Millennial to multi-decadal variability in the climate of southern Africa. International Journal of Climatology, 22, 1105-117. http://dx.doi.org/10.1002/joc.787

Van Heerden, J., Terblanche D. E., \& Schulze, G. C. (1988). The Southern Oscillation and South African summer rainfall. Journal of Climatology, 8, 577-597. http://dx.doi.org/10.1002/joc.3370080603

Washington, R., \& Preston, A. (2006). Extreme wet years over southern Africa: Role of Indian Ocean sea surface temperatures. Journal of Geophysical Research: Atmospheres (1984-2012), 111(D15).

\section{Copyrights}

Copyright for this article is retained by the author(s), with first publication rights granted to the journal.

This is an open-access article distributed under the terms and conditions of the Creative Commons Attribution license (http://creativecommons.org/licenses/by/3.0/). 